\title{
Dalit Development in India: A Political Economy Perspective
}

\author{
Kunhaman $\mathbf{M}^{*}$ \\ Professor at the Tata Institute of Social Sciences, India
}

Submission: October 10, 2018; Published: October 30, 2018

*Corresponding author: Kunhaman M, Professor at the Tata Institute of Social Sciences, Tuljapur Campus, Osmanabad District, Maharashtra State, India.

\section{Introduction}

'Development', despite its accrescent popularity since the Second World War, was never unambiguously defined; nor was there unanimity of views among scholars and policy- makers regarding its meaning, source and measure. Soon it morphed from a desideratum into an ideology, an article of faith and a magic wand for solving all the problems facing humanity all over the world. Rulers of various countries used it to intimidate people into accepting any project without dissent or disagreement even if people of the area/locality concerned did not want it. Thus, development became a de facto instrument for silencing people. This cure-all was deftly used as a red herring, as a refraction from basic issues such as primitive accumulation, dispossession and deprivation, socio-racial and political oppression, economic exploitation and ethnic cleansing.

Adam Smith, the father of economics, considered growth as being derived from an intransitive verb: growth is a process that a country undergoes. Each person, working in their selfinterest, this pre-capitalist economist visualized, as leading to the growth of the economy. It is not that when the country progresses, the individual invariably progresses also. There is no guarantee that when a country registers high economic growth, each one of its population will grow, whereas the other way around is sure to happen. In other words, development is not an epiphany; it is the sum of the outcomes of individual efforts made diachronically and synchronically. Development is being derived from a transitive verb, i.e. making development happen through purposeful interventions, is a post -World - War 11 phenomenon.

Development is a bourgeois concept. It was discovered along with other concepts like 'the people', 'the poor', the 'Third World', 'under development' etc. and the regions and people so designated were extended development assistance by the capitalist world with the ulterior motive of preventing the spread of Communist ideology (applying the domino theory) and the ingress of socialist ideas. The existing socialist world had, within a short period, proved its readiness for an eyeballto-eyeball confrontation with its puissant capitalist counterpart, sending capitalists the world over (not only in the capitalist bloc) into jitters. In the post-War period, scholars and planners busied themselves with the formulation of theories, models and strategies of development. Alongside emerged a panoply of dazzling plan models. All these were state-centric /state-led, i.e., quintessentially, bureaucratic soap operas. The cumulative outcome of all these was the emergence of a scenario wherein scholars think for the people, policy-makers make policies for the people, experts make programs and projects for the people, fussy civil servants implement them for the people and NGOs stand/'work' for the people. Everyone 'for the people'; everything 'for the people'. People themselves have no role in their own 'development.' The poor were deluded into thinking that they were facing a development problem, pulling the plug over the basic problems creating the paradoxical denouement: people not getting what they were asking for and getting what they were not asking for.

The above account, though staccato and kaleidoscopic, conveys, putatively, the let motif of the development pursued in the post-War period. Criticizing/ questioning development became sacrilege, for those who undertook development assumed themselves to be infallible, omniscient and omnipotent with the divine mandate to redeem and develop the poor ignoramus. However, it did not take long for the people to realize that they were shortchanged and taken for a ride. As time wore on, some perceptive and conscientious scholars thought aright, and people's conditions were going to pot; they asserted that development was dead and, therefore, it should be entombed [1-3] Now, we are talking about dalit development in the post-development era. The question is not about improving formulation and implementation of development programs/projects; nor is it about alternative development. It is about alternative to development. In this sense, state-directed development is passé for it means the negation of freedom. State-pushed development [4] must be interned and replaced by self - (i.e., individual-) directed development. State is religion; a secular religion. Both state and religion demand total obedience, compliance and obeisance; both punish dissent and noncompliance. 
A parliamentary democratic state is an elected religion. Collaterally, an authoritarian, though elected, ruler has no moral right to talk about freedom, democracy and equality, for these principles require rulers/ leaders not to talk for or talk to or talk at but to talk with people. Such rulers are a vanishing species. Often, elected rulers become threat to democracy and freedom. Moreover, as is often the case, pro-dalit policy decisions can be taken without dalit representation; conversely, anti-dalit decisions can be taken with dalit representation. Representation and the nature of policy-making are two different matters. When the dalits demand representation, it is not with certitude that they will be able to tilt the policy apparatus in their favor; it is quintessentially a democratic principle that they get representation, the David-and-Goliath-like process sure to happen, notwithstanding.

\section{Property is Freedom: Hegel}

Further, it may also be mentioned, end passant, that development is not for the poor. It is always and everywhere for the non-poor, i.e., for those who have a resource-base. Property is the source of development; and liberty/freedom is its force. In other words, freedom is the source of development; and property is the source of freedom. Amartya Sen regards development as freedom [5]. i.e., freedom from poverty, illiteracy, disease, shelter lessness etc. Freedom, thus, is the source of development and development, in its turn, should widen the scope of freedom. Besides, the Hegelian "identification of property and personality" [6] helps underline the seminal salience of property. For Hegel, property is itself freedom, [7] and any talk about freedom without property is idle and perfidious. Politics without a program of property redistribution should be debunked and denounced; and any political party without redistribution of property as the major plank must be shunned. Acquiring property is attaining freedom. Of course, in socialism and particularly after the state withers away, the producer will be, purportedly, re- united with the means of production. But, as things stand, hoping this to happen will be pie in the sky. This-worldly problems call for this-worldly solutions; one can reasonably think of attaining universal property rights through the legislative and market routes. State should be the provider and protector of universal private property. Universal adult suffrage and universal private property should be deemed as the obverse and reverse of the same thing; one cannot exist without the other.

It would be a travesty of history to hold that dispossession of the small producer is the outcome of market penetration. It was the use of force (including state force) that accomplished this. Since state, overtly and covertly, was the major instrument of dispossession, it should be, for the same reason, the major instrument of repossession. After ending alienation of the producer from the means of production, people should be left free to pursue their self-interest in the manner they deem fit. In other words, laissez faire policy as Adam Smith envisaged is the best policy. The poor (property less) and the nonpoor(propertied) are worlds apart. The never- poor will never understand the sufferings of the ever- poor. Never-the-less, it is they who are always entrusted with the responsibility of eliminating those sufferings. The world is now controlled by the victors who are invariably from rich sections. Only when the vanquished snatch power, the sufferings of the oppressed will get reflected in policies and programs.

\section{Dalits in the Polity, Economy, and Society}

Dalits have, of late, acquired high political visibility. However, they do not enjoy that visibility in the economy and society. B.R. Ambedkar "always emphasized that political democracy will be incomplete without economic and social democracy" [8]. "Social and economic democracy are the tissues and fiber of a political democracy. The tougher the tissue and fiber, the greater the strength of the body", he maintained in his tour be force in 1946. He was, indeed, building on his magnum opus published in 1936. In the Constituent Assembly, he sternly warned against the new contradiction that India would have to resolve, viz, equality in politics and inequality in the economy and society. Unless this contradiction was resolved at the earliest, he cautioned, the victims of the system would throw away the Constitution which the Constituent Assembly had so "laboriously built." He had rightly discerned that untouchables' poverty and backwardness were the source of material wealth and hence, the provenance of the strength and progress of others. The post-colonial India, which witnessed a transfer of power from Western rulers to the Westernized Indian rulers never introduced the kind of development policies required to resolve the contradiction.

The feudal-dynastic democracy only perpetuated the extant socio-economic inequalities and imbalances with all the disastrous consequences. Policies determine the priorities, pace, and pattern of development. Hence, the relevant question is whose ideas, thinking, and knowledge shape policies. After all, ideas cannot change a system; it is action that can. It is the ideas of those who have power that influence a system. To be accepted, ideas should move with power. In other words, power and ideas move together. This is precisely what happened to policy-making in post-Independence India. It was Nehru's thinking that shaped development policy in India. That thinking was elaborated in his book, The Discovery of India [9], wherein he emphasized the need for catching up with the developed countries, a need, not organic in evolution but extraneously grafted. Ambedkar's ideas did not influence policy-making in India; instead, they remained confined to sociological analysis. In this regard, Ambedkar was shortchanged.

\section{Two Routes}

Dalits had been the objects of 'administered development.' They had to traverse two routes: 1 . Welfare, both general and targeted; and 2. Affirmative action and reservation. Overall, the approach was in line with the welfare state as envisaged in Part IV of the Constitution. However, they were denied the opportunity to avail themselves of liberalism which is the spirit of the Constitution. In fact, the country pursued a two-track 
development path: a self-chosen one for the well-off and a government-pushed one for the poor. As far as the poor were concerned, the government, the failed God, was everywhere; an albatross around their neck. For them, liberty was (and still is) chimerical. In the name of welfare and development, they were presented with poor quality services, often proffered as a charity. Though Article46 of the Constitution mandates the State to protect the dalits (also the adivasis) from all sorts of discrimination, bondages and oppression (as well as to promote their interests), the state miserably failed in carrying out that mandate. Atrocities against dalits continue unabated and the state remains indifferent [10]. What is ironical in this regard is that now the dalits have representation and participation in the state.

This is testimony (if testimony is required) to the fact that state is an instrument of oppression [11] irrespective of its social composition, its benign simulacrum notwithstanding. In many a case, economic dependence accounts for increasing atrocities against dalits. The economy should be a sphere of autonomous activity, "unimpeded by political and religious restrictions". It is so for the non-dalits. Why can't it be so for the dalits? Why should the dalits perpetually suffer from the insidious syndrome of dependency on the state and on others in society? Can't they be let off the hook? The truculent and obstreperous politicians may obstruct, stymie and stultify any attempt at escape from the wretched and sweatshop conditions of a sub-human existence, forcing them to the Procrustean bed employing any heinous means. Politicians, after all, want a "precariat "to shout slogans, paste posters and get beaten up by police. Dalits should see through such machinations and turn their back on party/ partisan politics which denied them resource right. Freedom is not a birthday gift. Remember this dictum: be brilliant and bold, the oppressed will like you; be a slave, the oppressor will like you. The dalits, most importantly, must shed their sui generis traits such as fear, inferiority complex and diffidence created and perpetuated by the syndrome and this is possible only through entitlement to property. The tendency to aim at only community certificate-based salaried jobs must be replaced by aiming at becoming entrepreneurs, industrialists and businessmen.

Given the decline and near- disappearance of the leftist and working class movements( these two are not the same; the left, wherever it is still there does not represent the working class as it once did; it is an arrangement for power sharing with inevitable electoral trade-offs)), on what will follow the present neo-liberal, post-industrial capitalism, one has to keep one's fingers crossed. Or why worry: in the life of a person, there is nothing like a long run. Let's be concerned about the quotidian questions facing us in the immediate- and short-runs. Boom and bust must be taken in our stride. Some of the discerning and perceptive scholars who addressed this question leave it openended. The most notable study in this context is by Immanuel Wallerstein and others. In the book, Does Capitalism have a Future? they speculate on various possibilities [12]. Some of these are "shift from contemporary capitalism to a revamped future system $(2,3)$, and "a more egalitarian and prosperous world capitalist order". "Nobody can now specify the institutions and parameters of the world coming after capitalism".

\section{The Afro-Americans and the Dalits}

Not infrequently, parallels are drawn between the Blacks in the US and the dalits in India, the two most oppressed peoples in the world. While the US is the oldest democracy, India is the largest one. The American Constitution came into being in 1787 and the Emancipation Proclamation was signed by Abraham Lincoln on January1,1863 [13] but the Blacks got voting right only in 1965. The Swedish economist and sociologist, Gunnar Myrdal considered this denial of liberty/freedom to the Blacks as an American dilemma [14]. However, the Blacks who were determined to live down their prolonged history of slavery, seclusion and segregation, looked ahead and thought de novo. First, they proclaimed an ideology, "Black is Beautiful." Thereafter, they evolved a strategy, viz, "Buy Black" by which they meant boycotting White business. Unsurprisingly, this act of the blacks who were possessing vast amounts of purchasing power could potentially result in the collapse of white business. As a mitigating measure, White industry, business, and academia started giving special consideration to the Blacks. Many firms and universities started implementing affirmative action and giving preferences to the Blacks in employment and admissions. The Blacks realized the importance of private property and the spunk and spine it provided.

Independent India adopted measures which can be thought of as perfect foil for the American situation. "In America, the Negro's dark skin had much to do with his servitude" whereas in India, untouchability had much to do with the deprivation and despondency of the dalits. In the first general election itself, universal adult franchise was provided, thanks primarily to Ambedkar, for, it is not unreasonable to presume, hypothetically, that the upper caste elites could have limited the ambit of elections for reasons of illiteracy or untouchability. The Constitution gave the Indian a new identity. Till then, one had only a caste identity; one was a Brahmin, or a Muslim, or an untouchable. But hereafter, one could be a doctor, a teacher, or a lawyer. The concept of equality, however, remained in the Preamble to the Constitution without any concrete program for bringing it about. The question of inequality is serious, but it is beyond the scope of this Address. However, one-point bears emphasis, viz, that economic inequality is not the creation of the neo-liberal economic policy. Its genesis can be traced to precapitalist periods and the caste system was the basic reason for it defined and determined structure of ownership of property, division of labor, distribution of income and the appropriation and use of social surplus. What is relevant and important here is that new opportunities are opened which can be availed of on a secular basis leading to a weakening of the once-irreversible link between caste and the economic frontier that Baily stressed in 1957. P. Sivananda also, while investigating the theme decades 
later, found the relation still existing between caste and economic opportunities.

\section{Major Post-Independence Events}

\section{Planning}

Planning in India was launched in a feudal, hierarchically ordered, and egregiously unequal socio-economic structure. Major programs like Land Reforms and Green Revolution bypassed the dalits, the traditional landless tillers of the soil. They had to be satisfied with reservation in education, employment and politics. In the larger society, persons from property- owning groups came to occupy important positions. In every field, their positions have been at the top and their movements ever forward. There occurred what Gunnar Myrdal called "cumulative causation", i.e., to paraphrase Myrdal, initial advantages drawing more advantages. When systems change, persons in controlling positions in the preceding system come to occupy such positions in the new system as well. Look at the sociological background of the leading personalities in politics, academia, media, judiciary, science and technology etc. Everything like property, knowledge, English language are their preserve. They are the beneficiaries of the caste system, for it gave them freedom from poverty, feeling of superiority, courage and confidence. Of course, they have merit; but, then, merit is a social product, not God-given. What the ruling class called 'development' further widened and deeply entrenched inequalities. After all, development is not the concern of the deprived; it is in the interest of property/ resource-owning/ controlling groups and persons and, hence, their concern. Inexorably, two India's eerily co-existed: one controlling group, selectively including a few persons from marginalized/excluded groups with hopes, optimism, confidence and high aspirational mobility; the other hapless, helpless and hopeless, wallowing in poverty, illiteracy, and malnutrition and fatalism.

Increasing tertiarization and informalization [15] gave rise to a bourgeoning group of lumpenised dalit mass incapable of cognition and cogitation. Their ignorance and incomprehension deterred them from moving forward. Concertizing and mobilizing such a resigned group were, indeed, a historic, blockbuster, revolutionary [16] feat that Kanshiram and Mayavaty accomplished in the 1980s. The historical importance of the political mobilization of the dalits lies in the fact that it forced every political party to sit up and take note and redraw the contours of the differential political calculus. This process of dehumanization, Promethean awakening and phoenix-like plunge are taking place in the economic field also, as evidenced by the emergence of 'dalit capitalism', a masterstroke causing seismic waves in the power-dominated civil society, new social kinetics and redrawing the contours of the caste calculus.

\section{Dalit Capitalism}

The emergence of a few dalit capitalists in and around Pune has evoked wide interests for its novel and promising potential. Whether this brand of capitalism is structurally different from capitalism in general is beside the point. During the feudal period, no dalit could become a landlord for there was religious/ social sanction against it. And that situation continued till the end of the 1980s. In a society where, social relations defined and determined production relations, and where the cavernous caste system crushed and atrophied the untouchables, this is least surprising. It must be underscored that caste was not just a status group as Max Weber thought [17]; it was a socioeconomic group; at its hard core, class. Scholars like Weber lack a historical understanding of caste-class correspondence in India. The planning era could not raise the expectations of the dalits; but post-dirigiste, neo-liberal era could. Liberalism in its plenitude is secular and reassuring in throwing the iron grip of the caste hierarchy into the dustbin of history.

There is no value-free policy. Every policy formulation is assertion of value, the value of the dominant policy-maker [18]. Values, predilections and perspectives of the dirigisme regime are irrelevant and unworkable in the neo-liberal era wherein deconstructions and bench-markings de novo is called for. The post-colonial assertions of environment, gender, and identity, along with the spread of market not only as a process but, more importantly, as an ideology have had their irreproachable and irreversible imprint in society and culture, replacing primeval views and primordial values with new needs and new consumption patterns. It may be borne in mind that needs are historical and social and not just natural. With the heralding of the neo-liberal era, the socio-religious sanctions were lifted, and the economy was open. Neo-liberal economic policy is the apotheosis in the paradigm attic evolution that human history has witnessed. This is encapsulated in the epigrammatic statement, "A rising wave shifts all boats." "Utopias afford consolation heterotopias are disturbing" [19].

Innovation is the open sesame. Entrepreneurship is circumscribed only by socio-economic conditions and not by religious sanctions. The declaration by DICCI president, Milind Kamble, "We will be job givers, not job-seekers" opens a new chapter in the annals of Indian history with long legacies of caste oppression and social exclusion. This new confidence and hope should be kept alive. Many, poor, uneducated dalit women entrepreneurs have also been, in the novel sweepstakes, who emerged, "defying the odds" [20]; a fact without precedent and worthy of emulation by others, and indisputably with potential distortionary effect on the caste-class-gender axis. Dalits should produce Tatas, Birla's, Ambani's, and Adanis from among themselves [21]. They must become employers on an increasing basis. The Dalit's three-stage transition is worth keeping in mind here. With the advent of the Constitution, the dalit became a human being; with the mobilization by BSP, he became a political being; and with the emergence of the neo-liberal era, he became an economic being.

A defining feature of Indian society today is mobility; geographical, social, occupational and, above all, aspirational. There are very few legal restrictions on such mobility. Now, it 
is a question of ability to participate in the market economy. Market, of every type, is a secular process and a secular place. Becoming an employer of a few will be a far greater catalyst in secularization than giving a thousand lectures on secularism. Dalits deserve more than what they can get based on community certificates. Objectified dalit labor, congealed and coagulated in material wealth entitles them to lay claim to property which alone is the riddance and redemption for them. The community certificate reminds a dalit of his/her marginality. The new paradigm, dominated by technology and market, and centering innovation and social enterprise, gives one a new identity. The dalits must imbibe the values of Enlightenment, liberalism, and classical individualism. The triple alienation-from wealth, knowledge, and power- they have been subject to for centuries must be put an end to. Neo- liberalism has spawned a radical attitudinal change which must be sustained and further strengthened.

The radical intelligentsia, yet to emerge among the dalits, must rewrite history and rework imageries to get rid of the humiliating stereotypes. The position that only class struggles are struggles and all other struggles and movements are irrelevant are historically false, socially untenable, intellectually untrue and politically indefensible must be given a decent burial for history is replete with corroborating evidences that only social struggles( i.e., non-class struggles)of various huesethnic, racial, caste, gender, environmental-have challenged and changed situations and created history [22] . In the Indian context, multi-class 'Left' politics blocks any serious attempt at working class formation as well as the emergence and spread of socialist ideas. The parliamentary Left parties, like the Centre and Centre Right parties are coalitions of caste and class forces. No wonder, upper caste and upper-class persons continue to control those parties.

"Politics becomes a handmaiden to international capital markets instead of being responsive to genuine popular interests" [23]. The authors further point out the substantial leverage of business interests" and the "declining influence of electoral democracy] over policy formation.".Now, there are no capitalists; there are only investors who are given red carpet welcome by governments, national, regional and local. Capitalists are not surplus-value extractors and exploiters; they are employment creators/ providers. Class harmony rather than class conflict is the new focus. Noam Chomsky puts it unambiguously: "Jobs" has become the technical term for "profits"; it's considered improper to mention the word, "profits" in public discourse, so you may say jobs instead, and the important people understand that it means profits" [24,25]. Governments are falling head over heels in making their countries/states attractive investment destinations. They are seldom concerned with what their people think about them; they are ever and exclusively concerned with the judgement of the rating agencies. After all, people are mere voting animals. After elections, the democratically elected dictators make policies and take decisions with disdain and nonchalance. Recent experience shows that elections have become the process of making law-breakers law-makers.

The upwardly mobile dalits need to redefine and reposition themselves in meeting the new challenges (which are new opportunities) by creating competitive market conditions. This calls for eschewing pre-modern, feudal values like respect, obedience and fear, and becoming competitive, competent, innovative and risk-taking. After all, the world belongs to the bold. Liberty and freedom must be the driving forces. Liberation from "the notable persistence of feudalist attitudes" [24] and atrocities against dalits lies in creating an expansive dalit capitalist class and a radical dalit intelligentsia. And the opportunity for this was (or will be) never better. After all, the leftward movement of the Right and the rightward movement of the Left seldom surprise anybody with reasonable understanding of the compulsions involved in the desire to capture and remain in power in a parliamentary democracy. Career politicians are wont to make wanton compromises with caste and communal forces for the sake of sheer survival and it is heartening to note that the dalits have no ideological fixation whatsoever, and are seldom dirigible, a propitious condition for the unswerving pursuit of economic self-interest which is the best interest, notwithstanding the rather rhetorical question, viz, what selfinterest Mahatma Gandhi, Mother Theresa and Nelson Mandela had, forgetting , unpardonably, that social sciences are not about great people; they are about people in the ordinary business of life. Politics needs a relook; sometimes, total rejection. It is not the violence of the oppressor, but the silence of the oppressed that is frightening. Also, it needs mentioning that in a permanently evolving social world, ideologies and social science theories are tentative and conjunctural, spatio-temporal variations notwithstanding.

\section{References}

1. Escobar Arturo I (2014) Other Worlds are (Already) Possible. SelfOrganization, Complexity and Post-Capitalist Cultures. In: Savyasachi, Ravikumar (Eds.), Social Movements, Transformative Shifts and Turning Points. Routledge, Oxford, UK.

2. (1995) Encountering Development. The Making and Unmaking of the Third World, Princeton University Press, USA.

3. Rehnema Majid (1997) The Post-Development Reader. Zed Books, UK.

4. Kohli Atul (2004) State-Directed Development, Political Power and Industrialization in Global Periphery. Princeton University, New Jersey, USA.

5. Sen Amartya (1999) Development as Freedom. Oxford, UK.

6. Avineri Shlomo (1968) Social and Political Thought of Karl Marx. Cambridge University Press, Cambridge, UK.

7. Hegel (1820) The Philosophy of Right.

8. Dreze, Jean (2016) Introduction in Chomsky.

9. Nehru Jawaharlal (1946) Discovery of India.

10. Jare Ramesh, Sampath Kale (2017) Caste in modern India. Atrocities Against Dalits. Stadium Press, India.

11. Kannabiran KG (2004) The Wages of Impunity: Power, Justice, and Human Rights. Orient Black swan, India. 
12. Wallerstein (2013) Does Capitalism Have a Future? Oxford University Press, Oxford, UK.

13. Brink Wiliam, Louis Harris (1963) The Negro Question in America. A Clarion Book published by Simon and Schuster, New York, USA.

14. Myrdal Gunnar (1944) An American Dilemma. Harper\& Row.

15. Sanyal Kalyan (2007) Rethinking Capitalist development. Routledge, Oxford, UK

16. Jaffrelot C (2003) India's silent Revolution. The Rise of the Lower Castes in North India C Hurst \& Co Publishers. Ambedkar and untouchability.; Fighting the in-dean caste System. Columbia University Press, USA.

17. Weber Max (1968) Economy and Society, Westminster Press, New York, USA.

18. Wallerstein Immanuel (1979) The capitalist word Economy. Essays by Immanuel Wallerstein. Cambridge University press, USA.
19. Foucaul, Michel (1994) The Order of Things. Archaeology of Human Science. Vintage Books, New York, USA.

20. Kapur Devesh DS (2014) Defying the Odds.: The Rise of Dalit Entrepreneurs. Vintage Books, New York, USA

21. Kunhaman M (2017) Foreword to Jare and Kale.

22. Robinson Cedrick (1983) Black Marxism The Making and Unmaking of the Black Radical Tradition. The University of North Carolina Press, USA.

23. Beramendi Pablo (2015) Politics of Advanced Capitalism. Introduction. 24. Chomsky, Noam (2015) Democracy and Power. Three Essays Collective 25. Sivananda P (2006) Identity and Violence. Penguin Books, London, UK

\section{Your next submission with Juniper Publishers will reach you the below assets}

- Quality Editorial service

- Swift Peer Review

- Reprints availability

- E-prints Service

- Manuscript Podcast for convenient understanding

- Global attainment for your research

- Manuscript accessibility in different formats

(Pdf, E-pub, Full Text, Audio)

- Unceasing customer service

Track the below URL for one-step submission https://juniperpublishers.com/online-submission.php 